\title{
Optimal combination of food waste and maize husk for enhancement of biogas production: Experimental and modelling study
}

\author{
H.I. Owamah ${ }^{\mathrm{a}, \mathrm{b}, *}$, O.C. Izinyon ${ }^{\mathrm{a}}$ \\ a Department of Civil Engineering, College of Science and Engineering, Landmark University, P.M.B.1001, Omu-Aran, Kwara State, \\ Nigeria \\ ${ }^{\mathrm{b}}$ Department of Civil Engineering, Faculty of Engineering, University of Benin, Benin, Edo State, Nigeria
}

\section{H I G H L I G H T S}

- Optimum combination of $75 \% \mathrm{FW}$ and $25 \% \mathrm{MH}$ occurred in digester $\mathrm{B}$.

- Increase in $\mathrm{MH}$ above $25 \%$ decreased biogas production.

- Post hoc Test in ANOVA showed a significant difference in digesters' yields.

- Gompertz model simulation results corroborated the experimental findings.

\section{A R T I C L E I N F O}

\section{Article history:}

Received 3 February 2015

Received in revised form 3 October 2015

Accepted 15 October 2015

Available online 1 November 2015

\section{Keywords:}

Biogas optimization

Food waste

Maize husk

Gompertz modelling

Methanogenesis

\begin{abstract}
A B S T R A C T
This study was focused on the optimization of biogas production from the co-digestion of food waste (FW) and maize husk (MH). The co-digestion of FW and $\mathrm{MH}$ at various mixture ratios was carried out in digesters A to E at $37 \pm 1{ }^{\circ} \mathrm{C}$. Digesters $\mathrm{A}, \mathrm{B}, \mathrm{C}, \mathrm{D}$ and $\mathrm{E}$ contained FW: $\mathrm{MH}$ of $(100: 0 ; 75: 25 ; 50: 50 ; 25: 75 ; 0: 100)$ respectively. Results obtained showed that average biogas yields of $0.50 \pm 0.04,0.71 \pm 0.07,0.54 \pm 0.05,0.30 \pm 0.03$, and $0.24 \pm 0.02$ $\mathrm{L} / \mathrm{gVS}$ were obtained from digesters A, B, C, D, and E respectively. The modified Gompertz modelling of the experimental data showed that digesters A, B, C, D, and E had latency $(\lambda)$ of $4.1,4.9,6.9,7.4$, and 10.6 days respectively. Digester $B$ had the highest maximum specific biogas production $R_{m}$, and maximum biogas production potential (A) of $0.50 \mathrm{~L} / \mathrm{gVS} /$ day and $20.7 \mathrm{~L} / \mathrm{gVS}$ respectively. The $R^{2}$ values between experimental and simulation data ranged from 0.9913 to 0.9989 in all digesters. The Post hoc Test in ANOVA using the Least Significant Difference (LSD) confirmed that there were significant differences in the mean biogas yield from the different digesters. The study therefore shows that the best combination of FW and MH for enhanced biogas production occurred in digester B.
\end{abstract}

(C) 2015 Elsevier B.V. All rights reserved.

\section{Introduction}

Inadequate energy supply and environmental pollution are major problems in Nigeria and many other developing countries of the world (Owamah et al., 2014a; Owamah, 2014). With the tremendous increase in population, access to adequate energy and healthy environment demands for a diversification of sources of energy supply. For instance,

\footnotetext{
* Corresponding author. Tel.: +234 8035705814.

E-mail addresses: owamah.hilary@Imu.edu.ng, dahilla222@yahoo.com (H.I. Owamah), izinyon2006@yahoo.com (O.C. Izinyon).
} 
while South Africa, Brazil, UK and Germany have over 900, 500, 1340, $1500 \mathrm{~W} /$ person respectively, in Nigeria, available energy per person is less than 25 W (Onohaebi, 2014; Owamah and Izinyon, 2015a). This according to Oyedepo (2012), represents a serious energy crisis and has paralyzed many commercial and industrial enterprises in Nigeria. Globally, the high dependence on fossil energy fuels for industrial, commercial and domestic energy needs has resulted in climate change and related human health problems (Budiyono et al., 2010). The problem has even become worse by the recent continuous fall in the price of crude oil to less than \$ 50 US dollars per barrel since the start of the year 2015 (OPEC, 2015). The interest in renewable research and development has seen a huge increase within the last decade in a bid to proffer solutions to the problems of environmental pollution and depleting fossil reserves (Gueguim-Kana et al., 2012).

Amongst the renewable energy resources, anaerobic digestion of waste organic substances to biogas appears to be the most popular as it helps to generate bio-fuel, reduce environmental pollution and improve agricultural productivity through the use of its digestate as compost for organic farming (Alfa et al., 2014). Biogas comprises approximately 60\% methane and has an energy value between 5.4 and $6.4 \mathrm{kWhm}^{-3}$ (Hartman and Ahring, 2006). Since this is close to the energy value of the natural gas $\left(5.7-7.7 \mathrm{kWhm}^{-3}\right.$ ), biogas could be used as a substitute for the highly demanded natural gas (Hartman and Ahring, 2006).

The sustainability of large scale anaerobic digestion plants, however, depends much on the optimal combination of process factors. It is also important that substrates are obtained in the most cost-effective manner. This therefore requires process optimization. Co-digestion of two or more biodegradable substrates in a digester, has been used by several authors, for the optimization of the biogas production potential of digested substrates (Momoh and Nwaogazie, 2011; Alfa et al., 2014). All these notwithstanding, the best combination of various substrates for optimal biogas yield is still a challenge, despite the enormous number of potential substrates (Owamah et al., 2014b). It is worthy of note, that the biogas yield and methane content of anaerobic digestion process, are the two major factors necessary for the proper evaluation of the economic and technical feasibility of large scale anaerobic digestion plants (Francesco and Cinzia, 2009). Because food waste (FW) contains highly degradable substances and low nitrogen content, co-digestion with complementary substrates such as plant residues of lower biodegradability and high nitrogen content have been found to immensely boost both biogas yield and digester stability (El-Mashad and Zhang, 2010).

Maize husk $(\mathrm{MH})$ is one of the plant residues that is generated in large quantities in Africa. At the moment in Nigeria, $\mathrm{MH}$ is either disposed in 'open dumps', or burnt in the open air. These unscientific methods of disposal constitute potential health hazard and contributes immensely to global warming. Although Amon et al. (2007) had reported on biogas production from co-digestion of dairy manure and whole maize varieties, the problem of food insecurity in the world discourages using food resources for renewable energy generation.

There is indeed scanty information in literature on the best combination of FW and $\mathrm{MH}$ for optimal biogas production. The focus of this research therefore, is to determine the best combination of FW and $\mathrm{MH}$ for optimum biogas production through batch anaerobic co-digestion of varying percentages of FW and MH. The study further used the modified Gompertz model to simulate and fit the experimental data in order to determine relevant kinetic parameters for predicting the performance of digesters.

\section{Methods}

\subsection{Collection of materials}

FW used for this study was collected from waste bins of the Cafeteria at Landmark University, Omu-Aran, Kwara State. The collections were done on daily basis, within five working days of a week, from Monday 24th March to Friday 28th March, 2014. In accordance with the procedure in Owamah et al. (2014b), the food waste was collected at 12 noon and 7 pm of each day, to coincide with students' time of peak consumption and waste generation. The purpose of collecting FW over 5-working days was to reduce nutritional variations in the food waste collected. MH was obtained from Landmark University Farm, Omu-Aran, Kwara State. It was initially kept dry in a sack, in the Environmental Engineering Laboratory of Landmark University, prior to the commencement of the anaerobic digestion experiments.

Following the procedures used in Zhang et al. (2007), El-Mashad and Zhang (2010) and Owamah and Izinyon (2015a) the bones and inorganic materials in the food waste were sorted out within $24 \mathrm{~h}$ of collection. This was followed by the crushing and homogenization of the food waste using a mini electric blender. The blended FW was then kept in a freezer at approximately $4{ }^{\circ} \mathrm{C}$, before the commencement of anaerobic digestion experiment in April 10, 2014.

Following the procedure in Zhu et al. (2014), Owamah and Izinyon (2015b) the collected MH was ground to powdery form using a grinder. Ground MH was then kept in a container that was air tight until it was used for the experiment.

\subsection{Analysis of chemical parameters of the prepared food waste and maize husk substrates}

The prepared FW and MH substrates, before they were mixed together for anaerobic digestion experiments were analyzed for their relevant chemical parameters. The total solids (TS) and volatile solids (VS) were measured in triplicate according to the Standard Methods for the Examination of Water and Wastewater (APHA, 2012) using a laboratory oven (DHG-9053A, Controls, Italy). Following standard procedures in APHA (2012), the FW and MH substrates were also analyzed 
Table 1

Chemical characteristics of the prepared food waste and maize husk substrates.

\begin{tabular}{lcc}
\hline Parameter & Food waste & Maize husk \\
\hline $\mathrm{TS}(\%)$ & $26.6 \pm 0.3$ & $10.5 \pm 1.2$ \\
$\mathrm{VS}(\%)$ & $18.4 \pm 1.2$ & $8.6 \pm 0.8$ \\
$\mathrm{NH}_{4}^{+}-\mathrm{N}(\%)$ & $1.7 \pm 0.2$ & $0.8 \pm 0.2$ \\
$\mathrm{TKN}(\%)$ & $1.8 \pm 0.2$ & $0.7 \pm 0.2$ \\
$\mathrm{Cl}(\%)$ & $1.3 \pm 0.3$ & $1.8 \pm 0.5$ \\
$\mathrm{P}(\%)$ & $2.9 \pm 0.1$ & $3.7 \pm 0.1$ \\
$\mathrm{Ca}(\%)$ & $3.4 \pm 0.5$ & $0.8 \pm 0.3$ \\
$\mathrm{Mg}(\%)$ & $1.6 \pm 0.2$ & $1.9 \pm 0.1$ \\
$\mathrm{~K}(\%)$ & $3.5 \pm 0.3$ & $2.3 \pm 0.1$ \\
$\mathrm{~S}(\%)$ & $3.8 \pm 0.1$ & $4.1 \pm 0.4$ \\
$\mathrm{Na}(\%)$ & $3.4 \pm 0.3$ & $2.7 \pm 0.2$ \\
$\mathrm{pH}$ & $4.8 \pm 0.1$ & $7.2 \pm 0.9$ \\
$\mathrm{C} / \mathrm{N}$ ratio & $13 \pm 0.4$ & $74.3 \pm 2.1$ \\
\hline
\end{tabular}

Measurements were done on wet basis; Values are shown as mean \pm standard deviation $(n=3)$.

Table 2

Feeding substrate characteristics for the batch digestion.

\begin{tabular}{|c|c|c|c|c|c|}
\hline Parameter & Digester A & Digester B & Digester C & Digester D & Digester E \\
\hline FW: $\mathrm{MH}(\%)(w / w)$, based on total weight $(\mathrm{g})$ & 100:0 & $75: 25$ & $50: 50$ & $25: 75$ & $0: 100$ \\
\hline Total weight of sample (g) & 30 & 30 & 30 & 30 & 30 \\
\hline $\mathrm{VS}(\mathrm{g} / \mathrm{L})$ & 3.8 & 3.5 & 3.2 & 3.0 & 2.7 \\
\hline $\mathrm{PH}$ & 7.4 & 6.5 & 6.5 & 7.2 & 6.8 \\
\hline $\mathrm{C} / \mathrm{N}$ ratio & 12.8 & 23.4 & 26.8 & 35.1 & 68.6 \\
\hline
\end{tabular}

Measurements were done on wet basis (i.e. as total weight of wet sample); Food waste (FW); Maize husk (MH).

for $\left(\mathrm{NH}_{4}^{+}-\mathrm{N}, \mathrm{TKN}, \mathrm{Cl}, \mathrm{P}, \mathrm{K}, \mathrm{S}, \mathrm{Na}, \mathrm{Ca}, \mathrm{Mg}\right)$ using a direct-reading photometer (Palintest Photometer, models 7100 and 7500, ELE, England). Carbon content of the substrates were measured using standard procedures in APHA (2012). The initial pH values of the FW and MH substrates were measured using pH (PHS-3C, SEARCH TECH, UK). Weighing balance (KERN 572, KERN and SOHN, Germany) was used for measuring the mass of the substrates. The values of the chemical parameters obtained for each of the prepared food waste and maize husk substrates are shown in Table 1.

\subsection{Anaerobic digestion experiments}

The anaerobic digestion experiments were carried out on varying mixtures of FW and MH in order to determine the best combination of FW and MH for biogas production. The experiments were conducted in five identical $10 \mathrm{~L}$ digester reactors with $5 \mathrm{~L}$ working volume using computer controlled anaerobic digesters (Model PDANC, Edibon, Spain). The digesters' reactors were labeled A, B, C, D, and E. The volatile solids content of the feeding substrates (influent) for the batch anaerobic digestion experiment was determined before the loading of the substrates into the reactors of the digesters. Adopting the split plot design used by El-Mashad and Zhang (2010) and Owamah and Izinyon (2015a), a total of 5 treatments comprising different mixture percentage of food waste and maize husk (Table 2) were used in this study. The FW:MH mixture percentage, substrate weight, VS, C/N ratio and other determined parameters, for the first batch anaerobic digestion experiment are as shown in Table 2.

The percentage of the substrates (FW and $\mathrm{MH}$ ) were based on total fresh weight ( $\mathrm{g}$ ). The digesters were set up and operated following the procedures described in the Manufacturer's (EDIBON, Spain) User Manual, and Boe et al. (2010). The initial total solids (TS) of substrates in all reactors was kept at $8 \%$ through dilution with water in order to meet with the specified TS range for low solid wet anaerobic digestion and also to increase the fluidity of the substrates for ease of pumping by the peristaltic pumps. According to Tchobanoglous et al. (1993), a TS of 6\%-12\% is the best for low solid anaerobic wet digestion. The substrates were feed from an overhead influent tank into the reactors of the digesters through inbuilt peristaltic pumps and flow meters in the computer controlled anaerobic digester. The flow was set to the maximum of $7 \mathrm{~L}$ per day in order to fill the reactors of $5 \mathrm{~L}$ working volume within the period of $18-20 \mathrm{~h}$.

The inflow of substrate was terminated after the working volume of the reactors were completely filled. Anaerobic digestion for each reactor was terminated after 44 days, when either no measurable or significant biogas production was obtained. The anaerobic digestion was maintained at mesophilic temperature of $37 \pm 1{ }^{\circ} \mathrm{C}$ through an inbuilt water bath of the anaerobic digester. The volume of biogas produced was measured daily at 12 noon, through water displacement method from the volumetric tank of the anaerobic digester, following the method of Francesco and Cinzia (2009). The volumetric tank was graduated in millimeter. The conversion factor for determining the volume of biogas generated is $0.01628 \mathrm{~L}$ per millimeter. This shows that for a change of one millimeter in height of the tank, there is a displacement of 0.01628 liters, equivalent to the biogas produced. In line with Boe et al. (2010), the displaced water was initially acidified to pH 3 using 
Table 3a

Two factor ANOVA without replication of biogas yield.

\begin{tabular}{|c|c|c|c|c|c|c|}
\hline Source of variation & SS & df & MS & $F$ & $P$-value & $F$ crit \\
\hline Rows (Biogas yields across the five different digesters for each day) & 2.302752 & 21 & 0.109655 & 6.507959 & $3.32 \mathrm{E}-09$ & 1.725969 \\
\hline Columns (Daily biogas yield from each individual digester) & 3.128623 & 3 & 1.042874 & 61.89407 & $9.16 \mathrm{E}-19$ & 2.750541 \\
\hline Error & 1.061509 & 63 & 0.016849 & & & \\
\hline Total & 6.492883 & 87 & & & & \\
\hline
\end{tabular}

hydrochloric acid $(\mathrm{HCl})$, which was followed by the addition of sodium chloride $(\mathrm{NaCl})$, to prevent the dissolution of $\mathrm{CO}_{2}$ into water. The temperature and $\mathrm{pH}$ of the anaerobic digestion process during the digestion period was constantly measured online through the inbuilt sensors of the anaerobic digesters.

The experiments were run in duplicates and mean values of daily biogas produced were recorded. No inoculum was used in the first batch anaerobic digestion experiment as the objective of the experiment was only to find out the optimum combination of both substrates for biogas production. However, the study on the effects of inoculum on biogas production from the best performed digester is ongoing. The methane content of biogas was analyzed twice in a week using a gas chromatograph (GC), model GC122, manufactured by BUCK, China and equipped with a Stabilwax-DA column $(0.3 \mathrm{~m} \times 0.32 \mathrm{~m} \times 0.5 \mu \mathrm{m})$ and flame ionization detector (FID). Nitrogen gas was used as carrier gas and was used at a flow rate of $5.2 \mathrm{~mL} / \mathrm{min}$. The column and detector temperature were set at $40{ }^{\circ} \mathrm{C}$ and $200{ }^{\circ} \mathrm{C}$ respectively. All analyses were done in the Environmental Engineering Laboratory of Landmark University. A sample picture and flow diagram of the computer controlled anaerobic digester are shown in Fig. S1 and Fig. S2 (see Appendix A) respectively.

\subsection{Fitting of experimental data using the modified Gompertz model}

The popular modified Gompertz model given as Eq. (1) is used for estimating important kinetic parameters of anaerobic digestion process.

$$
A_{t}=A \exp \left\{-\exp \left[\frac{R_{m} \times e}{A}(\lambda-t)+1\right]\right\}
$$

Eq. (1) has been used by many authors for prediction of maximum biogas production potential, specific maximum biogas production and lag time (latency) (Li et al., 2014, Zhu et al., 2014, etc). Parameter A represents the maximum biogas production potential (L/gVS), $R_{m}$ is maximum specific biogas production (L/gVS/day) and $\lambda$ is latency (days), $t$ is time of biogas production (days), $A_{t}$ is cumulative biogas production (L/gVS). Eq. (1) was carefully used to fit experimental data of this study in order to determine some important kinetic parameters necessary for digester design and optimal operation of large scale anaerobic plants that would treat food waste and maize husk substrates. The solutions to Eq. (1) were obtained using the optimization tools of the Solver Function in Microsoft Excel 2010 version. A two way Analysis of Variance (ANOVA) at $5 \%$ significant level was used to statistically analyze biogas yields from the five digesters. In line with El-Mashad and Zhang (2010), Post Hoc Test in ANOVA was performed using the Least Square Difference at 5\% significant level ( LSD $\left._{0.05}\right)$ to confirm the presence or absence of variability in the mean biogas yield from the different digesters using Eq. (2);

$$
L S D=t \sqrt{2 M S E / n}
$$

where $t$ is the critical, tabled value of the $t$-distribution (two-tailed) with the degree of freedom (df) associated with Mean Square for Error (MSE), and $n$ is the number of scores used for calculating the means. Apart from $n$ which is 44 , all other values for solving Eq. (2) can be found in Table 3a and the standard student's- $t$ distribution table.

\section{Results and discussion}

\subsection{Biogas production at different FW and MH mixtures}

The daily record of biogas yield from the different mixtures of FW and MH in digesters A-E after anaerobic digestion for 44 days is shown in Fig. 1. Forty four days was taken as the appropriate solid retention time for the substrates as no measurable biogas production was obtained from any of the five digesters thereafter. The $\mathrm{pH}$ of digesters $\mathrm{B}, \mathrm{C}, \mathrm{D}$ and $\mathrm{E}$ was within the optimal range of 6.5-7.7 (Alfa et al., 2014). Digester A within the first 14 days of digestion had a pH of about 6.4 but thereafter decreased and remained constant at about 5.8, indicating possible signs of acidification as the digestion progressed. The average biogas yields of $0.50 \pm 0.04,0.71 \pm 0.07,0.54 \pm 0.05,0.30 \pm 0.03$, and $0.24 \pm 0.02 \mathrm{~L} / \mathrm{gVS}$ were obtained from digesters A, B, C, D, and E respectively. Digester B was found to have higher biogas yield than the other digesters, followed by digester $\mathrm{C}$. The least performed digester is digester $\mathrm{E}$ with $100 \% \mathrm{MH}$. This could have resulted from the very high $\mathrm{C} / \mathrm{N}$ ratio, above the recommended limit of 20-35 (Ghasimi et al., 2009; Ozturk, 2013), and higher lignin content (Momoh and Nwaogazie, 2011). While very high $\mathrm{C} / \mathrm{N}$ ratio results in acidification which inhibits methanogenic activities (Ozturk, 2013), high lignin content inhibits initial hydrolysis of substrates (Momoh and Nwaogazie, 2011) After the 44 days of digestion, 


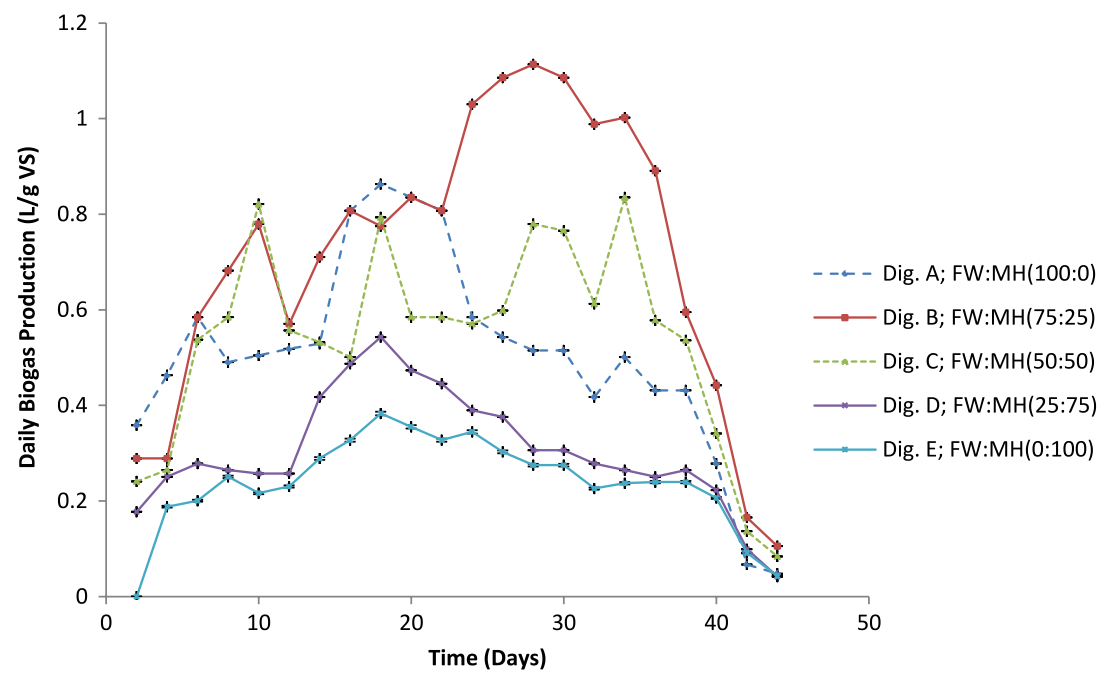

Fig. 1. Daily biogas production at the different mix ratios of FW and MH (food waste (FW); maize husk (MH), error bars are generally less than 0.05 ).

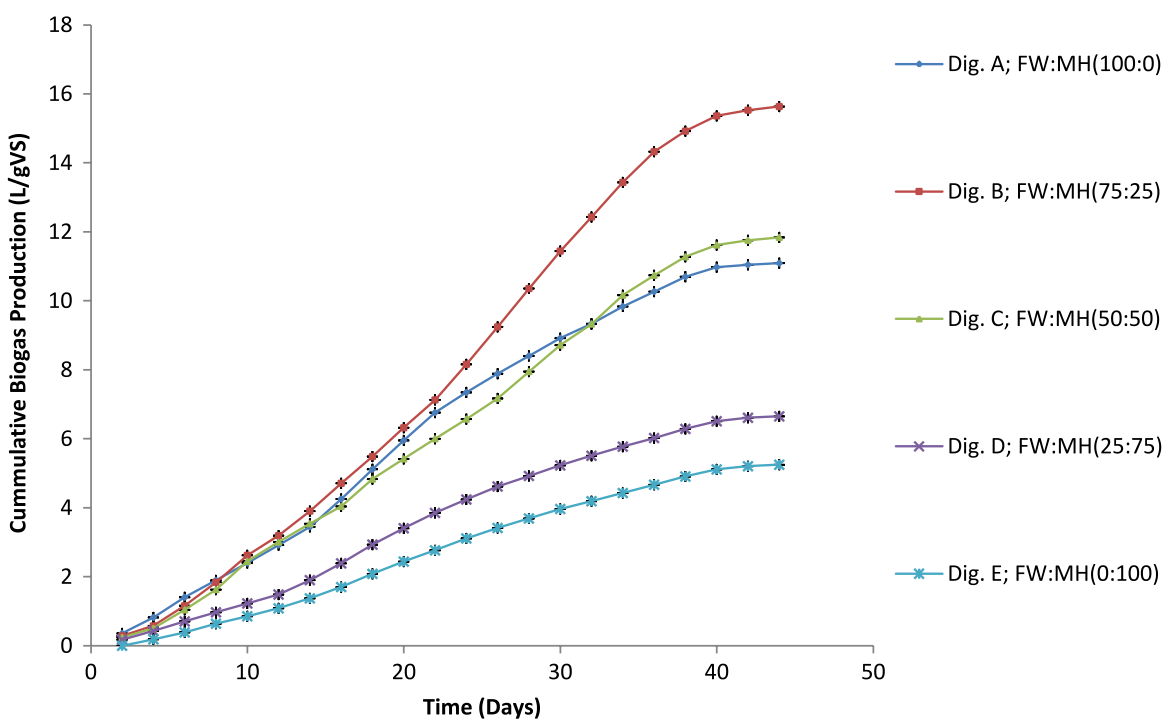

Fig. 2. Cumulative Biogas Production for the different mix ratios of FW and MH (food waste (FW); maize husk (MH), error bars are generally less than $0.05)$.

total biogas produced for digesters A, B, C, D and E was found to be 11.10, 15.64, 11.84, 6.65, and 5.24 L/gVS respectively (Fig. 2). The cumulative biogas production in Fig. 2 also indicates clearly that digester B had a more efficient performance in terms of biogas production than the other digesters.

Table 3a shows the statistical analysis, using a two-way analysis of variance (ANOVA) without replication $(p<0.05)$ of the biogas yield from the five digesters. From Table 3a significant difference in biogas yield from the different digesters was obtained. Substituting relevant values into Eq. (2), gave an $\mathrm{LSD}_{0.05}$ of $0.055 \mathrm{~L} / \mathrm{gVS}$. The differences in the mean biogas yield from the different digesters are as shown in Table $3 \mathrm{~b}$. Application of the obtained $\mathrm{LSD}_{0.05}$ of $0.055 \mathrm{~L} / \mathrm{gVS}$ to the mean differences in Table $3 \mathrm{~b}$ shows that all differences among the mean biogas yield from the digesters (Table 3b) were significant at $\alpha=0.05$. Biogas yield of digester D is however, comparatively similar to the yield of E. Both digesters (D and E) also had the largest amounts of maize husk. This therefore shows that though $\mathrm{MH}$ can help improve the biogas production potential of FW, very high proportion of $\mathrm{MH}$ in relation to FW could lead to inhibition and reduction of biogas yield in a digester. This finding is in line with the result obtained from the co-digestion of cow dung, water hyacinth and waste paper (Momoh and Nwaogazie, 2011), who reported that a continuous increase in the amount of wastepaper in the mixed substrate above the optimal combination led to a decrease in biogas yield. Momoh and Nwaogazie (2011) attributed this phenomenon to decrease in hydrolysis with increase amount of wastepaper.

After 32 days of digestion, 88.4, 85.9,85.8, 86.8, and 84.4\% of the total biogas yield were obtained from digesters A, B, C, D, and E. El-Mashad and Zhang (2010) had reported that over $80 \%$ of biogas yield was obtained within the first 20 
Table 3b

Differences in the mean biogas yield from the different digesters.

\begin{tabular}{lllll}
\hline Mean biogas yield & $\mathrm{A}(0.71 \mathrm{~L} / \mathrm{gVS})$ & $\mathrm{B}(0.54 \mathrm{~L} / \mathrm{gVS})$ & $\mathrm{C}(0.30 \mathrm{~L} / \mathrm{gVS})$ & $\mathrm{D}(0.24 \mathrm{~L} / \mathrm{gVS})$ \\
\hline $\mathrm{A}(0.71 \mathrm{~L} / \mathrm{gVS})$ & - & $(0.17)$ & $(0.41)$ & $(0.47)$ \\
$\mathrm{B}(0.54 \mathrm{~L} / \mathrm{gVS})$ & $(0.17)$ & - & $(0.24)$ & $(0.3)$ \\
$\mathrm{C}(0.30 \mathrm{~L} / \mathrm{gVS})$ & $(0.41)$ & $(0.24)$ & - & $(0.06)$ \\
$\mathrm{D}(0.24 \mathrm{~L} / \mathrm{gVS})$ & $(0.47)$ & $(0.3)$ & $(0.06)$ & - \\
\hline
\end{tabular}

Differences in mean are shown in brackets (), - indicates self comparison, which is unnecessary.

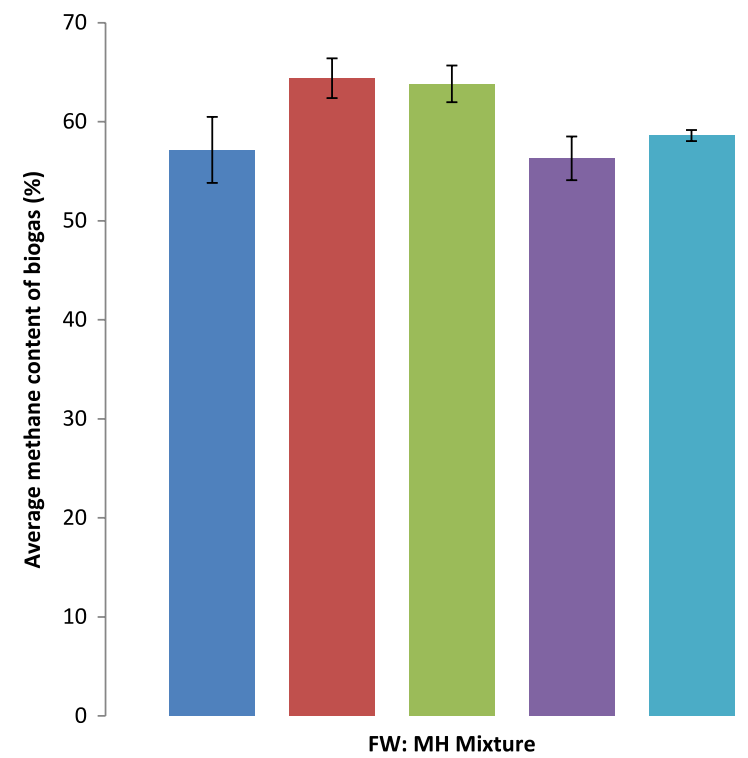

Dig. A; FW: $\mathrm{MH}(100: 0)$

Dig. B; FW: $\mathrm{MH}(75: 25)$

Dig. C; FW: $\mathrm{MH}(50: 50)$

Dig. D; FW: $\mathrm{MH}(25: 75)$

$\square$ Dig.E; FW: MH(0:100)

Fig. 3. Average methane content of biogas at different FM:MH mixtures (food waste (FW); maize husk (MH)).

days of commencement of anaerobic digestion of FW and cattle manure. Apart from digester B that had its peak biogas production of $1.11 \mathrm{~L} / \mathrm{gVS}$ on the 28th day, digester A, C, D, and E had their peak biogas production of $0.86,0.79,0.54$ and $0.38 \mathrm{~L} / \mathrm{gVS}$ respectively, on the 18th day of anaerobic digestion. Digester $\mathrm{C}$ was however found to have multiple peaks of similar magnitude (Fig. 1). The authors will investigate in detail the factors responsible for this pattern of multiple peaks in subsequent study. The higher biogas production in digester B could be attributed to better synergy of microorganisms in the digester as a result of the presence of some limited quantity of maize husk which led to the improvement of the $\mathrm{C} / \mathrm{N}$ ratio to 23.4 (Mata-Alvarez et al., 2000; Parawira et al., 2004). Fig. 3 shows the average methane contents of digesters A, B, C, D and E. Again, digester B with highest average biogas yield, also had cleaner biogas (in terms of methane content). It therefore follows that the anaerobic co-digestion of FW and MH for energy generation would do better when FW and $\mathrm{MH}$ are optimally combined at $75 \%$ and $25 \%$ respectively. This result thus shows that the co-digestion of FW with agro-wastes such as $\mathrm{MH}$ could enhance its biogas production when mixed optimally. Anaerobic co-digestion of FW and MH could therefore serve as a means of treating both wastes, with the added benefit of contributing to solving the energy problems in developing countries through biogas generation and utilization.

\subsection{Biogas production simulation and modelling}

Fig. 4 shows the simulation plot of experimental data using the modified Gompertz model for the different mixture ratios of FW and MH. Addition of some amount of MH was found to increase latency (Table 4). Latency $(\lambda)$ is the minimum expected time required for active methanogenesis to begin in anaerobic digestion. However, the difference in $\lambda$ for digester $A$ and $B$ was less than 1 day as digester A and B had $\lambda$ of 4.1 and 4.9 days respectively. The $R^{2}$ values between experimental data and simulation data of the modified Gompertz model, ranged from 0.9913 in digester E to 0.9989 in digester A (Table 4), showing that the experimental data were well simulated by the modified Gompertz model.

FW is generally known to contain large amount of easily degradable materials and indigenous bacteria. It thus tends to start producing biogas at the earliest time of digestion (Zhongtang et al., 2010). However, due to its low C/N ratio it usually suffers from acidification as a result of the excessive accumulation of intermediate products such as the volatile fatty acids (Zhongtang et al., 2010). This situation usually inhibits the subsequent production of biogas as the digestion time increases. It is therefore important to co-digest FW with agro-waste materials such as $\mathrm{MH}$, that have the capacity to adjust the $\mathrm{C} / \mathrm{N}$ ratio. Adjustment in $\mathrm{C} / \mathrm{N}$ ratio helps to reduce the problem of early acidification usually caused by low $\mathrm{C} / \mathrm{N}$ ratio and presence of high volatile organic components (Owamah and Izinyon, 2015a). 


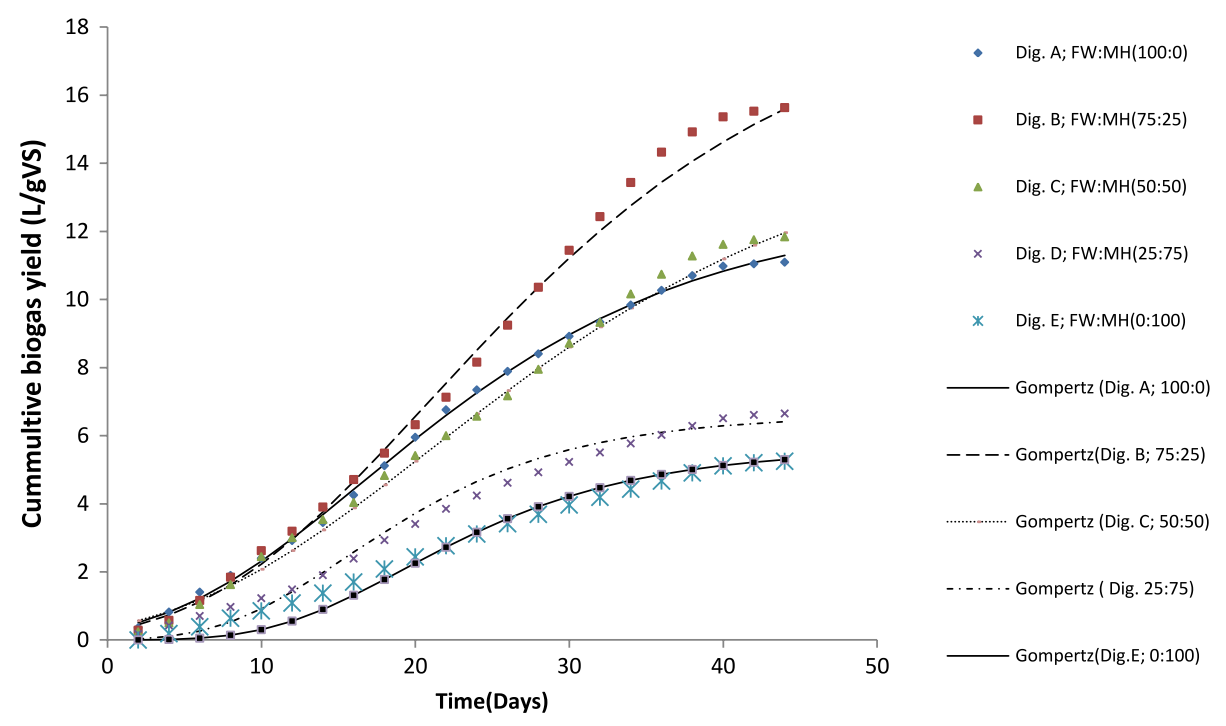

Fig. 4. Simulation of experimental data with modified Gompertz model at different FW and MH ratios (food waste (FW); maize husk (MH)).

Table 4

Modified Gompertz model parameters at the different mix ratios of FW and MH.

\begin{tabular}{llllcl}
\hline Digester & FW:MH mix ratio & $\mathrm{A}(\mathrm{L} / \mathrm{g}$ VS $)$ & $R_{m}$ (L/g VS/day) & $\lambda$ (Days) & $R^{2}$ \\
\hline A & $(100: 0)$ & 12.64 & 0.37 & 4.1 & 0.9989 \\
B & $(75: 25)$ & 20.71 & 0.50 & 4.9 & 0.9969 \\
C & $(50: 50)$ & 15.29 & 0.36 & 6.9 & 0.9965 \\
D & $(25: 75)$ & 6.60 & 0.30 & 7.4 & \\
E & $(0: 100)$ & 5.60 & 0.24 & 10.6 & 0.9913 \\
\hline
\end{tabular}

$\overline{\text { Food waste (FW); Maize husk (MH); Maximum biogas production potential (A), Specific maximum }}$ biogas production $\left(R_{m}\right)$, Latency $(\lambda)$.

The modified Gompertz modelling of the experimental data also shows that the addition of MH to FW increased the maximum specific biogas production of FW when the substrate comprised $75 \%$ food waste and $25 \%$ maize husk (Table 4). Further addition of $\mathrm{MH}$ to constitute $50 \%$ and $75 \%$ of the substrate decreased maximum specific biogas production. When FW was digested alone as found in digester A, $R_{m}$ was obtained as $0.37 \mathrm{~L} / \mathrm{gVS} /$ day. An improvement in $R_{m}$ to $0.50 \mathrm{~L} / \mathrm{gVS} / \mathrm{day}$ was obtained in digester B. After this optimum combination at digester B, further increase in MH percentage as obtained in digesters C, D, and E decreased $R_{m}$ (Table 4). This further shows the fact that for efficient operation of industrial biogas plants co-digesting FW and MH, the optimum combination of FW and MH could be taken as $75 \%$ and $25 \%$ respectively. $R_{m}$ is not just only related to the amount methanogens during digestion but also to their activities and equilibrium balance (Boulanger et al., 2012). It therefore suggests that in digester B, there was a better robust activity of methanogens which invariably made the rate of biogas production and substrate consumption maximal (Boulanger et al., 2012).

The modified Gompertz model furthermore, shows that the digestion of FW alone (digester A) had a maximum biogas production potential (A) of $12.64 \mathrm{~L} / \mathrm{gVS}$. A great increase to $20.71 \mathrm{~L} / \mathrm{gVS}$ was however obtained in digester $\mathrm{B}$. As the amount of $\mathrm{MH}$ increased beyond $50 \%$ in the substrate, maximum biogas production potential (A) began to reduce. Table 4 shows the different values of $(A)$ obtained from each digester. The decrease in $(A)$ observed in digesters $D$ was $47.6 \%$, while the increase in $\mathrm{A}(\mathrm{L} / \mathrm{gVS})$ obtained in digester $\mathrm{B}$, and $\mathrm{C}$ was $64.3 \%$ and $21.4 \%$ respectively, having digester $\mathrm{A}$ with $100 \% \mathrm{FW}$ as control. The improvement of biogas yield in digester B suggests that a different and more efficient degradation had occurred in the digester with the introduction of $25 \% \mathrm{MH}$ which would have probably led to a different metabolic pathway or access to new substrate (Boulanger et al., 2012). However, the decrease in (A) in digesters C and D could be explained by the fact that agro-wastes generally contain large amount of lignin which in excess concentration can make hydrolysis the limiting reaction path way, thereby reducing biogas yield (Owamah and Izinyon, 2015a).

\section{Conclusion}

The study was carried out to determine the best combination of food waste (FW) and maize husk (MH) for optimum biogas production. The highest average biogas yield of $0.71 \pm 0.07 \mathrm{~L} / \mathrm{gVS}$ was obtained in digester $\mathrm{B}$. Highest maximum biogas production potential $(\mathrm{A})$, and maximum specific biogas production $\left(R_{m}\right)$ were also obtained in digester $\mathrm{B}$ that contained $75 \% \mathrm{FW}$ and $25 \% \mathrm{MH}$. Increasing the content of $\mathrm{MH}$ beyond $25 \%$ was found to decrease $(\mathrm{A})$ and $\left(R_{m}\right)$, and to increase the minimum time required for active methanogenesis to begin (latency, $\lambda$ ). Excessive increase in latency with decrease in 
(A) is an evidence of inhibition/digester failure as observed in digesters $\mathrm{D}$ and $\mathrm{E}$. The adjustment of $\mathrm{C} / \mathrm{N}$ to optimum value as obtained in digester B was partly responsible for its enhanced biogas yield. The study therefore shows that anaerobic co-digestion of $75 \% \mathrm{FW}$ and $25 \% \mathrm{MH}$ could be the most suitable for optimum production of biogas.

\section{Appendix A. Supplementary data}

Supplementary material related to this article can be found online at http://dx.doi.org/10.1016/j.eti.2015.10.001.

\section{References}

Alfa, M.I., Adie, D.B., Igboro, S.B., Oranusi, U.S., Dahunsi, S.O., Akali, D.M., 2014. Assessment of biofertilizer quality and health implications of anaerobic digestion effluent of cow dung and chicken droppings. Renew Energy 63, 281-286.

Amon, T., Amon, T., Kryvoruchko, T., Zollitsch, W., Mayer, K., Gruber, L., 2007. Biogas production from maize and dairy cattle manure-influence of biomass composition on the methane yield. Agric Ecosyst Environ 118, 173-182.

APHA, 2012. Standard methods for examination of water and waste-water, 22nd ed.. American Public Health Association, Washington (DC, USA).

Boe, K., Damien, J.B., Jean-Phillippe, S., Irini, A., 2010. State Indicators for monitoring the anaerobic digestion process. Water Res 44, 5973-5980.

Boulanger, A., Pinet, E., Bouix, M., Bouchez, T., Mansour, A.A., 2012. Effect of inoculum to substrate ratio (I/S) on municipal solid waste anaerobic degradation kinetics and potential. Waste Manage 32, 2258-2265.

Budiyono, , Widiasa, I.N., Johari, S., Sunrso, , 2010. The kinetic of biogas production rate from cattle manure in batch mode. Int J Chem Biol Eng 3 (1), 39-44.

El-Mashad, H.M., Zhang, R., 2010. Biogas production from co-digestion of dairy manure and food waste. Bioresour Technol 101, 4021-4028.

Francesco, F., Cinzia, B., 2009. Biogas production from different substrates in an experimental continuously stirred tank reactor anaerobic digester. Bioresour Technol 100, 5783-5789.

Ghasimi, S.M.D., Idris, A., Chuah, T.G., Tey, B.T., 2009. The effect of C: N: P ratio, volatile fatty acids and Na+levels on the performance of an anaerobic treatment of fresh leachate from municipal solid waste transfer station. Afr J Biotechnol 8 (18), 4572-4581.

Gueguim-Kana, E.B., Oloke, J.K., Lateef, A., Adesiyan, M.O., 2012. Modeling and optimization of biogas production on saw dust and other co-substrates using Artificial Neural Network and Genetic Algorithm. Renew Energy 46, 276-281.

Hartman, H., Ahring, B.K., 2006. Strategies for the anaerobic digestion of organic fraction of municipal solid waste: an overview. Water Sci Technol 53 , $7-22$.

Li, Y., Zhang, R., He, Y., Zhang, C., Liu, X., Chen, C., 2014. Anaerobic co-digestion of chicken manure and corn stover in batch and continuous stirred tank reactor (CSTR). Bioresour Technol 156, 342-347.

Mata-Alvarez, J., Mace, S., Llabres, P., 2000. Anaerobic digestion of organic solid waste: an overview of research achievements and perspectives. Bioresour Technol 74 (1), 3-16.

Momoh, O.L.Y., Nwaogazie, I.L., 2011. The effect of waste paper on the kinetics of biogas yield from the co-digestion of cow dung and water hyacinth. Biomass Bioenergy 35, 1345-1351.

Onohaebi, S., 2014. Darkness at sunrise in Nigeria: Illuminating the dark spot before the sunset. In: 146th Inaugural Lecture, University of Benin, Benin, Nigeria.

OPEC, 2015. http://www.opecweb/en/923.htm. Downloaded by 11.30 am Ngerian time on the 3rd of October, 2015.

Owamah, H.I., 2014. Biosorptive removal of $\mathrm{Pb}(\mathrm{II})$ and $\mathrm{Cu}(\mathrm{II})$ from wastewater using activated carbon from cassava peels. J Mater Cycles Waste Manage 16 , $347-358$.

Owamah, H.I., Enaboifo, M.A., Izinyon, O.C., 2014a. Treatment of wastewater from raw rubber processing industry using water lettuce macrophyte pond and the reuse of its effluent as biofertilizer. Agric. Water Manag. 146, 262-269.

Owamah, H.I., Dahunsi, S.O., Oranusi, U.S., Alfa, M.I., 2014b. Fertilizer and sanitary quality of digestate biofertilizer from the co-digestion of food waste and human excreta. Waste Manage 34, 747-754.

Owamah, H.I., Izinyon, O.C., 2015a. The effect of organic loading rates (OLRs) on the performances of food wastes and maize husks anaerobic co-digestion in continuous mode. Sustainable Energy Technol Assess 11, 71-76.

Owamah, H.I., Izinyon, O.C., 2015b. Development of simple-to-apply biogas kinetic models for the co-digestion of food waste and maize husk. Bioresource Technol 194, 83-90.

Oyedepo, S., 2012. Energy and sustinable development in Nigeria: the way forward. Energy Sustainabil Soc 2 (15).

Ozturk, B., 2013. Evaluation of biogas production yields of different waste materials. Earth Sci Res 2 (1).

Parawira, W., Murto, M., Zvauya, R., Mattiasson, B., 2004. Anaerobic batch digestion of solid potato waste alone and in combination with sugar beet leaves. Renew Energy 29, 1811-1823.

Tchobanoglous, G., Theisen, H., Vigil, S., 1993. Integrated solid waste management engineering: principles and management issues. McGraw-Hill US, Singapore.

Zhang, R., El-Mashad, H.M., Hartman, K., Wang, F., Liu, G., Choate, C., Gamble, P., 2007. Characterization of food waste as feedstock for anaerobic digestion. Biores Technol 98, 929-935.

Zhongtang, Y., Mark, M., Floyd, L.S., 2010. Production and utilization of methane biogas as renewable Fuel. In: Alain, A.V., Nasib, Q., Hans, P.B., Hideaki, Y. (Eds.), Biomass to biofuels. John Wiley and Sons, Ltd..

Zhu, J., Yi, Z., Fuqing, X., Yebo, L., 2014. Solid-state anaerobic co-digestion of hay and soybean processing waste for biogas production. Biores Technol 154, $240-247$. 